\title{
Pengaruh katalis zeolit alam pada pirolisis plastik polyethylene terephthalate dan polypropylene
}

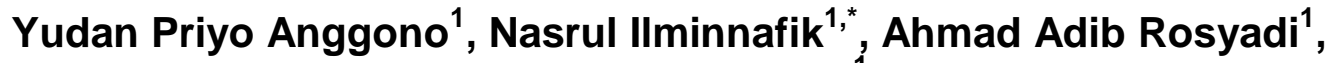 \\ Gaguk Jatisukamto ${ }^{1}$
}

\author{
1Jurusan Teknik Mesin Fakultas Teknik Universitas Jember \\ Jl. Kalimantan 37 Jember 68121
}

Naskah diterima 24/01/2020; direvisi 01/04/2020; disetujui 17/04/2020 doi: https://doi.org/10.24843/JEM.2020.v13.i01.p04

\begin{abstract}
Abstrak
Penggunaan plastik akan semakin meningkat seiring dengan bertambahnya jumlah populasi penduduk dan meningkatnya perkembangan teknologi. Meningkatnya sampah plastik menjadi masalah besar bagi kehidupan dan ekosistem, Karena plastik sulit terurai di dalam tanah dan membutuhkan waktu yang lama untuk dapat terurai. Dengan adanya permasalahan tentang banyaknya sampah plastik yang sulit di uraikan maka dapat dilakukan dengan metode pirolisis, metode pirolisis adalah proses pemanasan sampah plastik dengan menggunakan sedikit oksigen atau tanpa oksigen di dalamnya. Untuk memperbaiki minyak hasil pirolisis maka ditambahkan katalis sebagai katalisator sehingga memperoleh hasil minyak pirolisis lebih baik. Tujuan penelitian ini adalah untuk mengetahui perbedaan minyak PET (polyethylene terephthalate) dan PP (polypropylene), untuk membandingkan hasil pirolisis dari penggunaan katalis dan tidak menggunakan katalis terhadap viskositas minyak yang dihasilkan, serta pengaruh waktu pemanasan terhadap hasil volume minyak pirolisis. Dari penelitian yang dilakukan didapatkan hasil minyak terbanyak dengan bahan plastik PP dengan katalis $33 \mathrm{ml}$ atau 8,46 \%, PET katalis $23 \mathrm{ml}$ atau 8,943\% dan minyak PP tanpa katalis $76 \mathrm{ml}$ atau 19,26\%, PET tanpa katalis $65 \mathrm{ml}$ atau 17,23\%.
\end{abstract}

Kata kunci: Plastik, pirolisis, katalis, hasil minyak

\section{Abstract}

The use of plastic will increase along with the increasing population and increasing technological development. Increased plastic waste is a big problem for life and ecosystems, because plastic is difficult to decompose in the soil and requires a long time to be decomposed. With the problem of the amount of plastic waste that is difficult to describe, it can be done with the pyrolysis method, the pyrolysis method is the process of heating plastic waste using little or no oxygen in it. To improve the pyrolysis oil, the catalyst is added as a catalyst to obtain better pyrolysis oil results. The purpose of this study was to determine the differences in PET (polyethylene terephthalate) and PP (polypropylene) oils, to compare the results of pyrolysis from the use of catalysts and not use catalysts to the viscosity of the oil produced, as well as the effect of heating time on the results of the pyrolysis oil volume. The results of the research showed that most PP plastic catalyst oils were $33 \mathrm{ml}$ or $8.46 \%$, catalyst PET $23 \mathrm{ml}$ or $8.943 \%$ and PP oil without catalyst $76 \mathrm{ml}$ or $19.26 \%$, PET without catalyst $65 \mathrm{ml}$ or $17.23 \%$.

Keywords: Plastic, pyrolysis, catalyst, oil

\section{Pendahuluan}

Sampah dapat didefinisiskan sebagai semua buangan yang dihasilkan dari aktivitas manusia dan hewan berupa padatan yang dibuang karena sudah tidak dibutuhkan (Tchobanoglous dkk.,1993). Menurut Sucipto (2012) jenis sampah dibagi menjadi 3 bagian yaitu sampah organik, anorganik, dan B3 (bahan berbahaya dan beracun). Sampah organik merupakan sampah yang berasal dari makhluk hidup baik hewan ataupun tumbuhan. Sampah organik dibagai atas dua bagian yaitu organik dengan sifat basah dan organik dengan sifat kering organik dengan sifat basah adalah sampah organik yang kandungan airnya sangat banyak dan organik dengan sifat kering adalah sampah organik yang kandungan airnya sangat sedikit. Plastik sangat dibutuhkan dalam aktivitas kehidupan manusia.

Plastik adalah bahan baku yang sangat mudah digunakan, sifatnya yang ringan, elastis, kuat, transparan, fleksibel, dan tahan terhadap air adalah faktor kelebihan dan keuntunga menggunakan plastik didalam kehidupanshari hari. Ketergantungan terhadap plastik dalam kehidupan sehari-hari baik dalam rumah tangga maupun dalam industri dapat menimbulkan permasalahan yaitu bertambahnya jumlah sampah plastik yang dihasilkan. Sampah plastik berbeda dengan sampah organik gang dapat terurai oleh bakteri. Sampah plastik akan berdampak negatif bagi lingkungan karena tidak dapat terurai dengan cepat dan untuk dapat menguraikan sampah plastik di alam dapat membutuhkan waktu yang lama (Maryudi dan Setyawan, 2014). Pada dasarnya plastik adalah sampah yang dapat didaur ulang tetapi ada juga yang tidak dapat didaur ulang. Menurut Syarief (1991) ada dua jenis plastik yaitu termoplastik dan termoseting. Termoplastik adalah plastik yang bersifat dapat didaur ulang contoh plastik termoplastik adalah PET (Polyethylene Terephthalate), HDPE (High Density Polyetylene), PVC (Polyvinyl Cheloride), LDPE (Low Density Polyethylene), PP (Polypropylene), PS (Polystyrene), O (Other). Plastik termoseting adalah plastik yang ketika sudah dibentuk atau dilunakan, sehingga jika dipanaskan kembali tidak dapat dibentuk 
ulang karena sifatnya hanya sekali proses pelunakan, contohnya plastik PU (Poly Urethene) dan UF (Urea Formaldehyde). Meningkatnya jumlah sampah plastik maka semakin besar pula timbunan sampah plastik yang di hasilkan, sehingga perlu adanya inovasi yang dapat mengurangi bertambahnya timbunana sampah. Salah satunya dengan mengolah sampah menjadi bahan bakar alternatif dan juga dapat menghasilkan poduk yang berguna dan bermanfaat adalah dengan metode pirolisis (Achilias, dkk, 2007).

Metode pirolisis adalah salah satu upaya baru yang telah dilakukan oleh peneliti dengan mengubah limbah plastik menjadi sumber energi baru dengan metode alternatif yang dapat digunakan untuk mengolah sampah organi maupun anorganik dengan sedikit oksigen atau tanpa oksigen (Ermawati, 2011). Proses pirolisis umumnya berlangsung pada suhu 300-500, pada suhu tersebut plastik akan meleleh dan beruhah menjadi gas sehingga rantai panjang hidrokarbon akan terpotong menjadi rantai pendek, selanjudnya mengalami pendinginan dan terkondensasi sehingga membentuk cairan pirolisis (Syamsiro, 2015). Pada proses pirolisis produk yang digunakan adalah sampah plastik dan otput yang diproleh adalah minyak, arang dan gas (Buekens dan Huang, 1998). Faktor yang dapat mempengaruhi pirolisis sehingga pirolisis dapat berjalan lambat atau cepat dan dapat mempengaruhi hasil keluaran adalah waktu, temperatur, berat partikel, ukuran partikel, dan juga ada salah satu faktor lain yang dapat mempengaruhi hasil minyak pirolisis yaitu penambahan katalis.

Pada proses pirolisis keberadaan katalis menjadi hal yang posistif karena dapat menurunkan kebutuhan energi dibanding dengan proses pirolisis termal juga berfungsi menurunkan waktu reaksi dan katalis dapat memperbaiki kualitas dan kuantitas hasil keluaran (Syamsiro, 2015) katalis zeolit dibagi atas dua macam yaitu katalis zeolit alam dan katalis zeolit sintestis katalis zeolit alam adalah katalis dalam pross pembentukannya dibentuk oleh alam tanpa penambahan zat dan dan campuran zat, zeolit alam terbentuk karena adanya proses kimia dan fisiks yang kompleks dari batuan batuan yang mengalami berbagai macam perubahan di alam. Zeolit sintetis adalah suatu senyawa kimia yang mempunyai sifat fisika dan kimia yang sama dangan zeolit alam, yang dibuat dari bahan lain dengan proses sintetis. Pada umumnya penggunaan katalis akan menurunkan fraksi minyak dan residu serta meningkatnya fraksi gas jika dibanding dengan degradasi termal (Syamsiro, 2015).

\section{Metode Penelitian}

\subsection{Bahan}

Penelitian ini dilakukan secara eksperimen dengan membuat alat pirolisis berupa tabung reactor yang dibuat dari tabung LPG $12 \mathrm{~kg}$ yang dipanaskan dengan kompor gas seperti ditunjukkan pada Gambar 1. Bahan penelitian berupa plastik sebagai bahan penelitian yaitu polypropylene (PP) dan polyethilene terephthalate (PET).

Plastik PP dan PET diperoleh dari pengumpulan sampah yang sudah tidak digunakan atau tidak diperlukan masyarakat. Plastik PP atau PET yang sudah dikumpulkan dibersihkan dan dijemur hingga kering dan dicacah untuk memperkecil ukuran plastik sampai dimensi $\pm 1 \times 1 \mathrm{~cm}$, dan plastik siap digunakan sebagai bahan pembuatan minyak pirolisis. Bahan ini dimasukkan ke dalam reactor yang dipanaskan sampai $380{ }^{\circ} \mathrm{C}$.

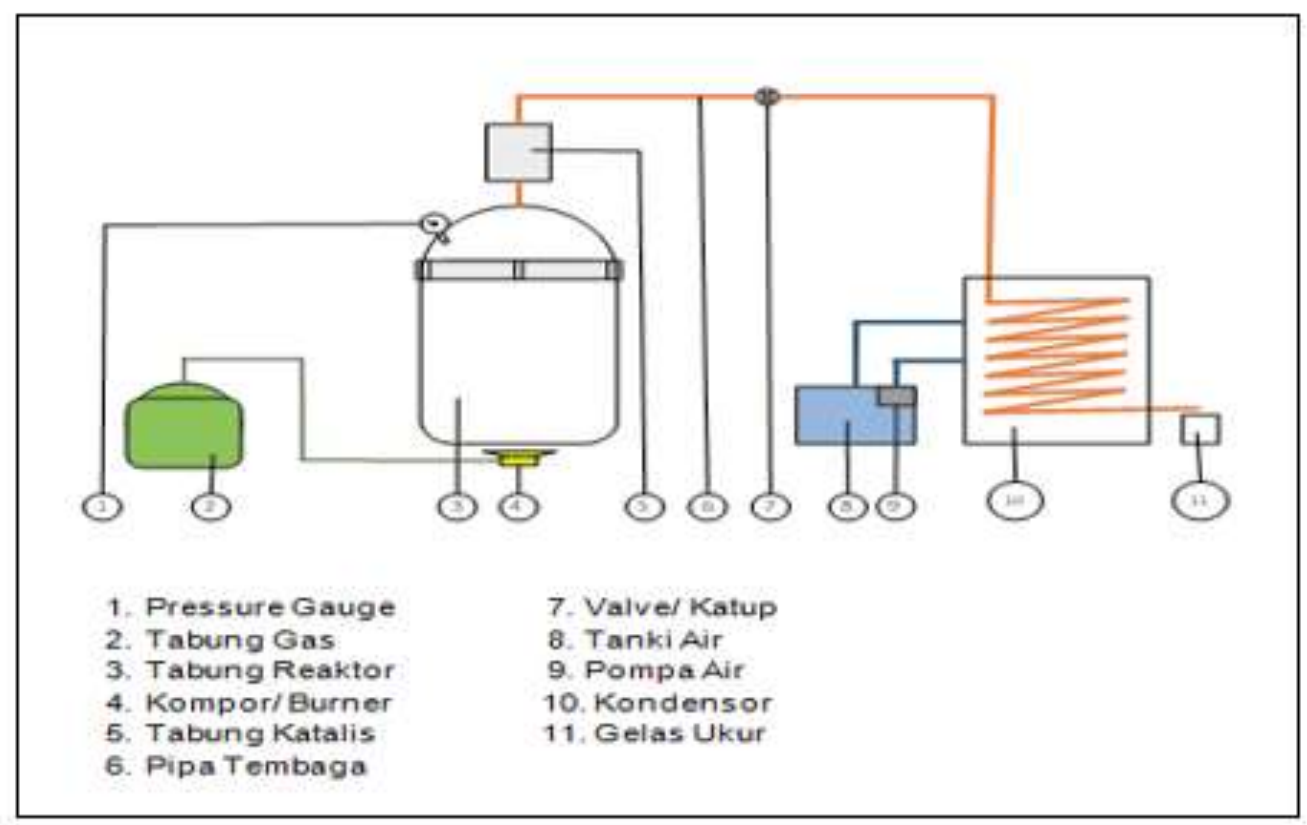

Gambar 1. Skema alat pirolisis

Sebelum digunakan, katalis yang berupa zeolit alam diaktifkan dengan cara di panasan pada suhu $200^{\circ} \mathrm{C}$ selama 30 menit. Tujuan pemanasan ini supaya pori pori katalis terbuka dan juga dapat 
membersihkan kotoran yang masih melekat pada katalis sehingga katalis lebih bersih.

Bahan plastik sebanyak 300 gram dimasukkan reactor yang dipanaskan pada suhu $380 \mathrm{C}$, selama variasi waktu 30 menit, 40 menit, dan 50 menit. Untuk optimalisasi hasil, dilakukan pendinginan pada gas yang dihasilkan dalam proses pirolisis seperti ditunjukkan pada Gambar 1. Cairan yang dihasilkan ditampung dalam gelas ukur sehingga diketahui hasilnya (ml). Untuk mengetahui kualitas cairan yang akan digunakan sebagai bahan bakar ini, kemudian diuji densitas, viskositas, flash point, dan angka oktannya.

\section{Hasil dan Pembahasan}

\subsection{Perbandingan pirolisis plastik PP dan PET}

Pada penelitian pirolisis dengan menggunakan bahan baku plastik PP dan PET, dilakukan perbandingan hasil proses pirolisis antara kedua bahan plastik kersebut, seperti ditunjukkan pada Gambar 2.

Perbandingan dilakukan pada plastik bahan baku pirolisis tanpa katalis dengan diketahui hasil pirolisis pada grafik, hasil liquid hasil arang dan hasil gas. Pada hasil liquid perolehan minyak PP lebih banyak diperoleh dari minyak PET. Polypropylene adalah jenis plastik yang memiliki sifat mekanis yang baik dengan masa jenis yang rendah, ketahanan panas dan kelembaban, serta memiliki kesetabilan dimensi yang baik (Maryudi dan Setyawan, 2014).

Hasil arang pada minyak PP lebih banyak dibanding PET dikarenakan hasil arang pada plastik PP lebih basah dibanding arang dari plastik PET lebih kering. Hasil gas pada pirolisis plastik PET lebih banyak daripada plastik PP dikarenakan plastik PET menghasilkan gas yang sulit dikondensasikan lebih banyak.

Penggunaan katalis pada pirolisis plastik PP dan PET dapat mempengaruhi proses pirolisis dengan perbandingan hasil liquid, arang, dan gas. Hasil liquid pada pirolisis katalis lebih banyak plastik PP dari pada plastik PET, akan tetapi minyak pada plastik PET memiliki masa jenis lebih besar dibanding plastik PP sehingga pada Gambar 3 hasil liquid menunjukkan angka lebih banyak di banding plastik PP.

Untuk hasil arang yang didapat plastik PP lebih banyak dari plastik PET dengan jumlah 96 gram, dan untuk hasil gas pada pirolisis plasti PET lebih banyak dari plastik PP dikarenakan plastik PET menghasilkan gas yang sulit untuk dikondensasikan lebih banyak.

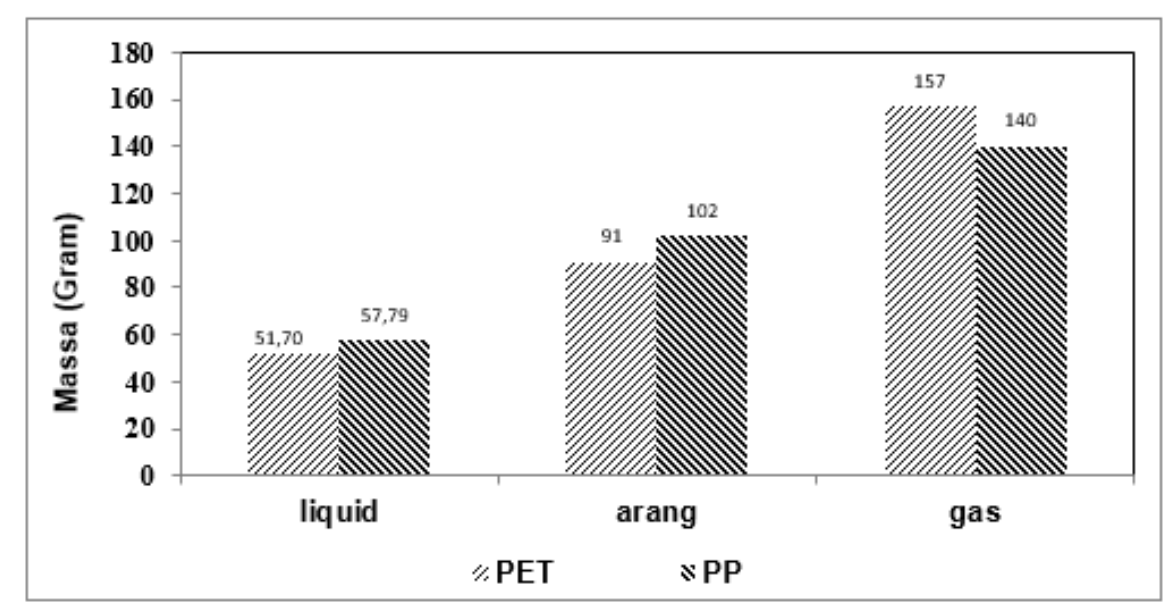

Gambar 2. Perbandingan hasil pirolisis tanpa katalis plastik PP dan PET

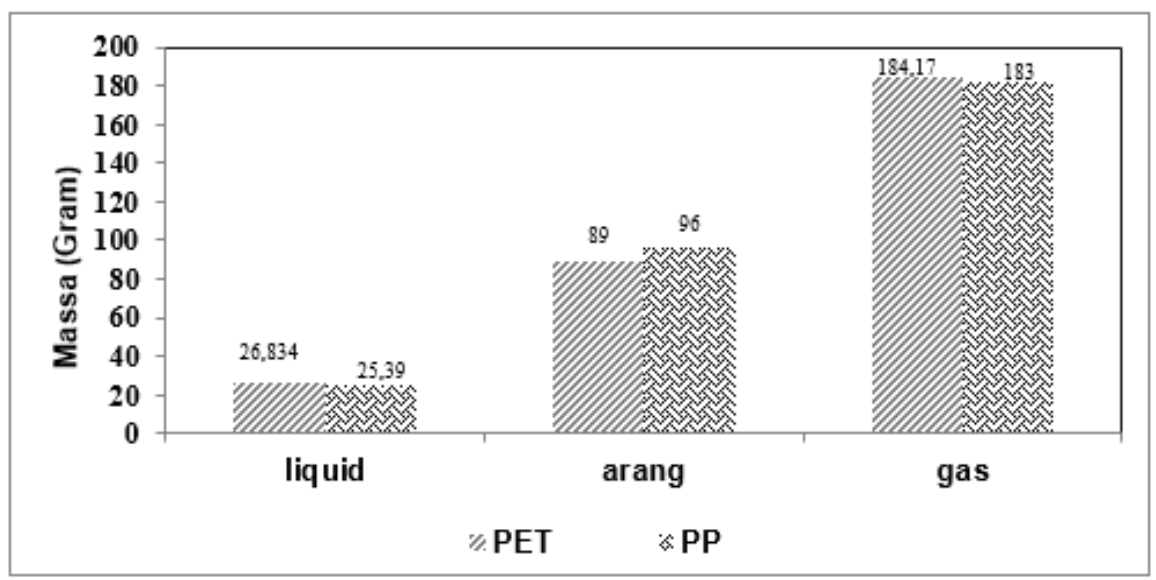

Gambar 3. Perbandingan pirolisis menggunakan katalis plastik PP dan PET 
3.2. Pengaruh waktu penahanan temperatur dan katalis terhadap hasil minyak, arang dan gas pirolisis

Pada penelitian pirolisis menggunakan plastik PP dan PET dengan menggunakan katalis zeolit alam yang terletak pada luar tabung reaktor. Dimana penggunaan katalis luar tabung dan waktu penahanan temperatur sangat berpengaruh terhadap minyak yang dihasilkan dari proses pirolisis plastik. Pada penelitian plastik PP dan PET sesuai dengan Wanchai dan Chaisuwan (2013) semakin tinggi suhu yang digunakan, maka nilai konversi yang dihasilkan juga semakin banyak, seperti ditunjukkan pada Gambar 4.

Hasil perolehan minyak pirolisis menggunakan katalis berbeda dengan hasil perolehan minyak pirolisis tanpa menggunakan katais. Hasil minyak yang diperoleh lebih banyak tanpa menggunakan katalis dibanding dengan menggunakan katalis, faktor yang Berdasarkan grafik perolehan minyak dapat dipengaruhi adanya katalis dan waktu penahanan, sehingga dapat disimpulkan bahrawa semakin lama waktu penahanan temperatur maka semakin banyak minyak yang dihasilkan dari proses pirolisis. Minyak dengan hasil terbanyak dari pengujian diperoleh pada waktu pemanasan 50 menit sebanyak PP tanpa katalis 57,79 gram atau $76 \mathrm{ml}$, PET tanpa katalis 51,70 garam atau $65 \mathrm{ml}$, PP katalis 25,39 gram atau $33 \mathrm{ml}$, PET katalis 26,834 gram atau $23 \mathrm{ml}$.

Perolehan minyak terbanyak pada waktu 50 menit. Hal ini disebabkan karena semakin lama waktu penahanan maka ikatan rantai karbon pada plastik terputus sehingga minyak yang dihasilkan semakin banyak (Houshmand dkk, 2013). Pada proses pirolisis dengan menggunakan katalis dapat mempengaruhi hasil minyak yang diperoleh dikarenakan katalis bersifat absorb mudah menyerap dan melepas cairan, sifat dari katalis tersebut dikarenakan katalis memiliki permukaan yang berpori-pori sehingga katalis memiliki sifat mudah menyerap.

Hasil arang pada proses pirolisis dapat dipengaruhi karena adanya waktu penahanan, jadi semakin lama waktu penahanan maka arang yang dihasilkan akan semakin sedikit dikarenakan arang ikut terbawa bersama gas pirolisis (Gambar 5). Pada penelitian ini didapatkan empat jenis arang yaitu arang darai plastik PP, PET, PP katalis, dan PET katalis, untuk hasil arang pengujian tanpa katalis berbeda dengan pengujian menggunakan katalis, pada pengujian tanpa katalis hasil arang lebih banyak dibandingkan dengan pengujian menggunakan katalis dikarenakan dari penggunaan katalis berfungsi menurunkan waktu reaksi inisiasi dan juga katalis dapat memperbaiki kualitas dan kuantitas hasil keluarannya (Syamsiro, 2015).

Hasil arang yang di peroleh pada pengujian berbeda beda dikarenakan pengaruh dari lama tahanan temperatur dan penggunaan katalis, hasil terbanyak yang diperoleh pada waktu penahanan 30 menit dengan tanpa katalis mendapatkan hasil plastik PP tanpa katalis 134 gram , PET tanpa katalis 127 gram, dan hasil pada penggunaan katalis dengan hasil PP katalis 122 gram , PET katalis 117 gram. Proses pirolisis didapatkan hasil berupa gas pada pengujia, hasil gas dapat dipengaruhi adanya waktu tahanan temperatur. Pada setiap pengambilan data dilakukan penahanan selama 30 menit, 40 menit, dan 50 menit, hasil penahanan dapat mempengaruhi hasil gas pada proses pirolisis, yaitu semakin lama waktu maka hasil gas akan semakin banyak dikarenakan lamanya pemanasan dan di imbangi dengan pengurangan padatan yang ada pada tabung reaktor.

Dari percobaan plastik PET lebih banyak menghasilkan gas dari plastik PP, dan penggunaan katalis dapat pempengaruhi hasil gas menjadilebih banyak dibandingkan tanpa katalis. Plastik PET tidak menghasilkan gas yang terkondensasi karena PET memiliki sifat dasar mudah menyublim (Rachmawati dan Herumurti, 2015). Hasil gas terbanyak pada plastik PP dan PET dengan menggunakan katalis dan lama waktu penahanan 50 menit diperoleh hasil pas plastik PP katalis 182,60 gram dan PET katalis 184,16 gram, sedangkan plastik PP dan PET kandungan gas yang dihasilkan lebih sedikit yaitu PP mencapai 140,22 garam dan sedangkan plastik PET katalis 157,30 garam (Gambar 6).

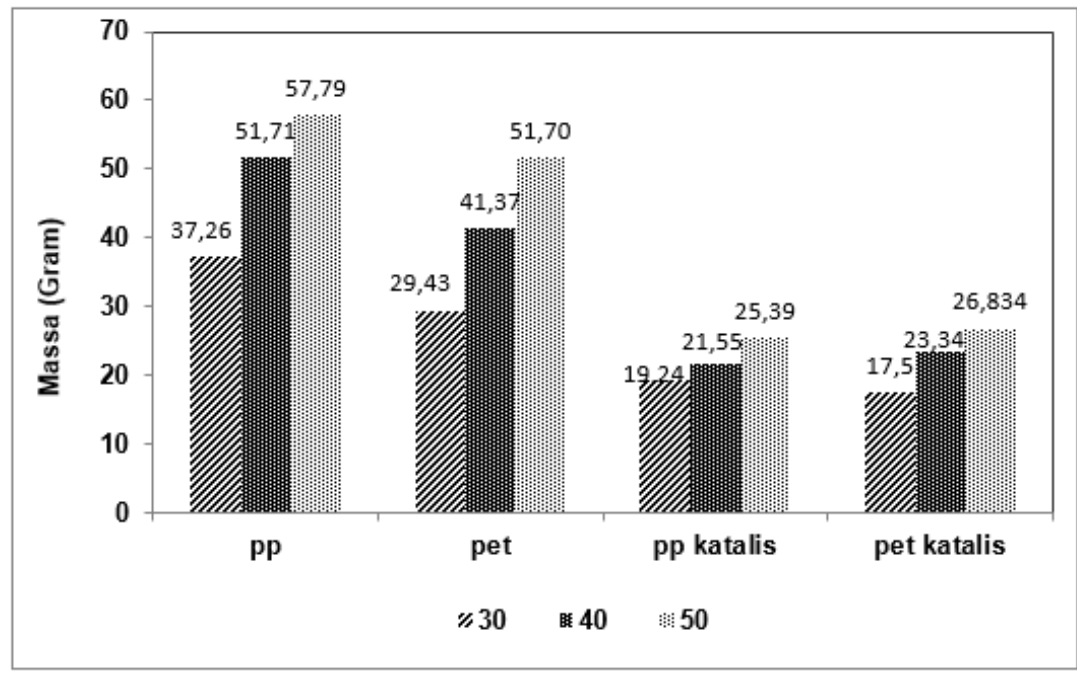

Gambar 4. Perbandingan jumlah minyak yang dihasilkan 


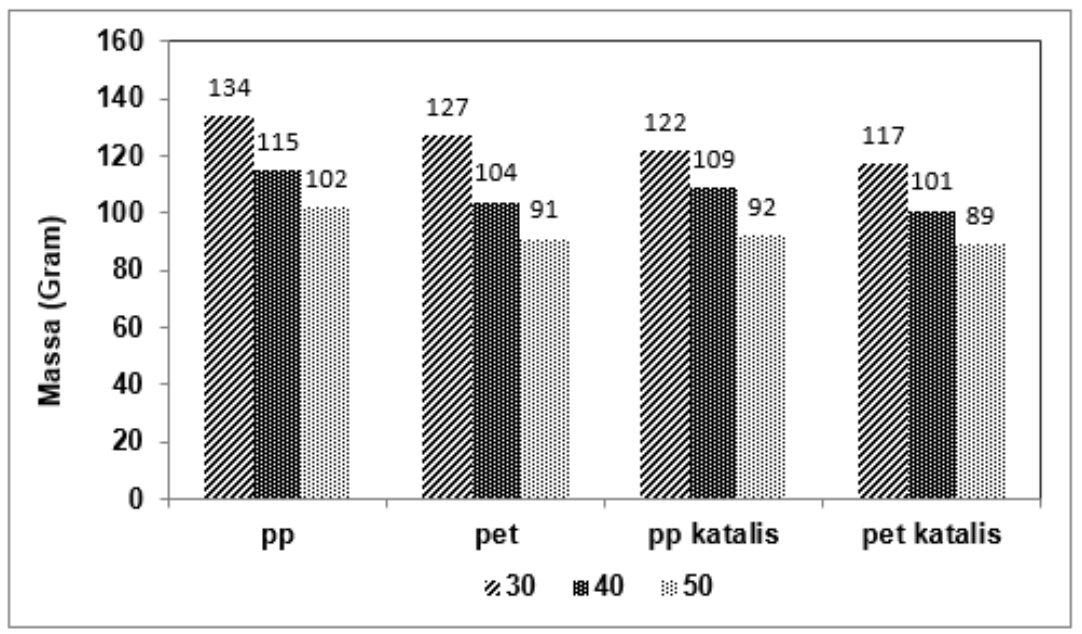

Gambar 5. Pengaruh waktu penahanan dan katalis terhadap hasil arang

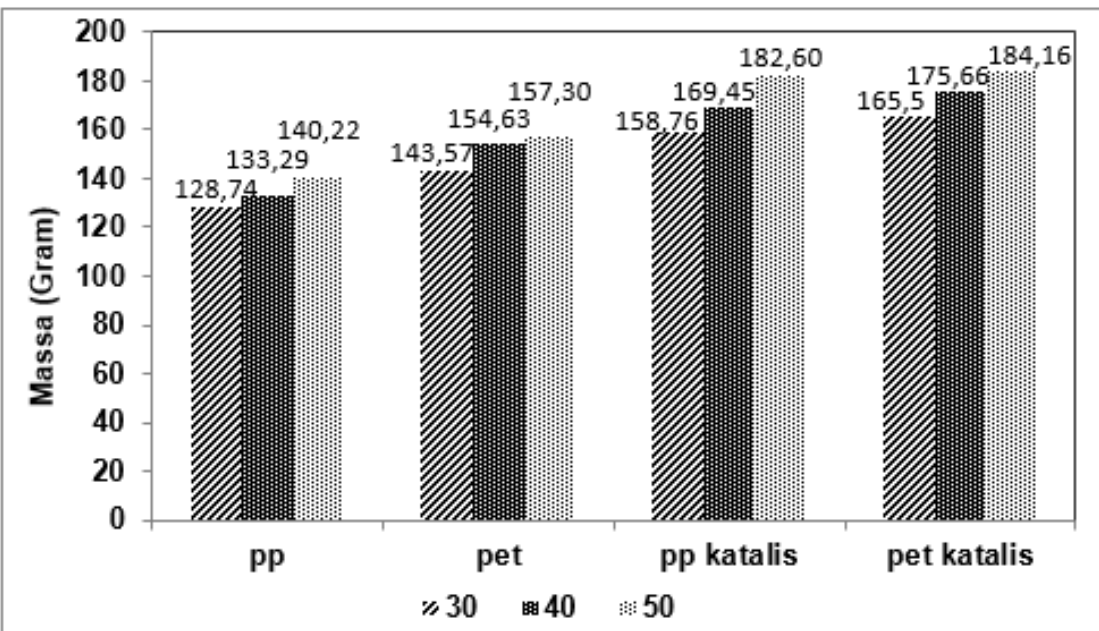

Gambar 6. Pengaruh waktu terhadap hasil gas pada pirolisis

Tabel 1. Pengujian karakteristik minyak PP dan PET

\begin{tabular}{|c|c|c|c|c|}
\hline Karakteristik & PP & PET & $\begin{array}{c}\mathrm{PP} \\
\text { katalis }\end{array}$ & $\begin{array}{c}\text { PET } \\
\text { katalis }\end{array}$ \\
\hline $\begin{array}{c}\text { Densitas } \\
(\mathrm{gr} / \mathrm{ml})\end{array}$ & $\begin{array}{c}0,7604 \\
\mathrm{gr} / \mathrm{ml}\end{array}$ & $\begin{array}{c}0,7954 \\
\mathrm{gr} / \mathrm{ml}\end{array}$ & $\begin{array}{c}0,7695 \\
\mathrm{gr} / \mathrm{ml}\end{array}$ & $\begin{array}{l}1,167 \\
\mathrm{gr} / \mathrm{ml}\end{array}$ \\
\hline $\begin{array}{l}\text { Viskositas } \\
\text { (dPa.s) }\end{array}$ & $0,3 \mathrm{dPa}$.s & $0,3 \mathrm{dPa} . \mathrm{s}$ & $0,4 \mathrm{dPa} . \mathrm{s}$ & - \\
\hline $\begin{array}{l}\text { Flash point } \\
\left({ }^{\circ} \mathrm{C}\right)\end{array}$ & - & - & - & - \\
\hline Nilai oktan & 75 & 68 & 77 & - \\
\hline
\end{tabular}

Hasil minyak plastik polypropylene (PP) dan Poliethylene Terephthalate (PET) dari proses pirolisis dengan menggunakan variabel waktu penahanan temperatur dan katalis zeolite alam selanjutnya dilakukan pengujian karakteristik minyak dengan menggunakan pengujian densitas, viskositas, flash poin, dan nilai oktan dapat dilihat pada Tabel 1.

Pada proses pirolisis plastik PP dan PET dengan varriabel waktu penahanan temperatur dan katalis zeolite alam menghasilkan minyak plastik yang mudah terbakar. Hasil yang didapat pada pengujian minyak menunjukkan beberapa minyak yang tidak keluar hasilnya pada pengujian flash point. pada pengujian flash point hasil pengujian tidak keluar dikarenakan pada pengujian minyak yang di uji terbakar sebelum suhu $60^{\circ} \mathrm{C}$. Minyak yang dihasilkan pada proses pirolisis tergolong dalam minyak ringan. Pada plastik PP katalis hasil minyak yang diperoleh mudah memadat pada suhu ruangan sehingga tidak bisa dilakukan pengujian viskositas, flash point, dan nilai oktan, dengan diketahui titik leleh pada minyak yaitu $52^{\circ} \mathrm{C}$.

\section{Simpulan}

Penelitian tentang proses pirolisis untuk mengetahui pengaruh katalis pada proses pirolisis dengan bahan 
plastik PET dan PP terhadap kualitas bahan bakar yang dihasilkan telak dilakukan dengan penahanan pada temperatur $380^{\circ} \mathrm{C}$, selama 30,40 , dan 50 menit.

Dari hasil-hasil penelitian bisa disimpulkan sebagai berikut:

a. Katalis meningkatkan masa jenis produk pirolisis, dimana pada plastik PP tanpa katalis $0,76 \mathrm{gr} / \mathrm{ml}$, PP dengan katalis $0,769 \mathrm{gr} / \mathrm{ml}$ dan PET tanpa katalis memiliki masa jenis $0,79 \mathrm{gr} / \mathrm{ml}$, PET katalis $1,167 \mathrm{gr} / \mathrm{ml}$.

b. Penahanan waktu mempengaruhi jumlah produk, dimana pda penahanan 50 menit dihasilkan produk paling banyak pada kedua jenis plastic yang diteliti.

c. Penggunaan katalis luar tabung reaktor dapat mempengaruhi minyak yang dihasilkan dari proses pirolisis menjadi lebih jernih dan juga dapat mempengaruhi hasil nilai viskositas cairan.

\section{Daftar Pustaka}

[1] Tchobanoglous, G., Theisen, $H$, dan Vigil, $S$. Integrated solid waste management. New York: Mc Grow- Hill. 1993.

[2] Sucipto, C. D. Teknologi pengolahan daur ulang sampah. Yogyakarta: Gosyen Publising. 2012.

[3] Maryudi dan Setyawan, M. Karakteristik sampah plastik pembungkus terseleksi untuk proses pilrolisis. Simposium nasional teknologi terapan . 2: 39-43. 2014.

[4] Syarief, R. Teknologi penyimpanan pangan. Jakarta: Penerbit arcan. 1991.

[5] Syamsiro, M. Kajian pengaruh penggunaan katalis terhadap kualitas produk minyak hasil pirolisis sampah plastik. Jurnal Teknik. 5: 47-56. 2015.

[6] Buekens, A.G., dan Huang, H. Catalytic plastics cracking for recovery of gasoline rage hidrocarbon from municipal plastic waste. Resources. Concervation and Recycling. 23: 163-181. 1998.

[7] Achilias, D.S., Roupakias. Waste C., Megalokonomos, P., Lappas, A.A, dan Antonakou, A. Chemical recycling of plastic waste made from polyethylene (LDPE and HDPE) and polypropylene (PP). Journal Of Hazardous Material. 149: 536-542. 2007.

[8] Ermawati, R. Konversi limbah plastik sebagai sumber energi alternatif. Balai besar kimia dan kemasan, kementrian perindustrian. 5: 257-263. 2011.

[9] Rachmawati, Q, dan., Herumurti, W. Pengolahan sampah secara pirolisis dengan variasi rasio komposisi sampah dan jenis plastik. Jurnal Teknik 4: 27- 29. 2015.

[10] Wanchai, K., dan Chaisuwang, A. Catalytic Cracking of polypropylene waste over zeolite bet
Waste over zeolite Beta. Cemistry and Materials Research. 3: 62-69. 2013.

[11] Houshmand, D., Roozbehani, B, dan Badakhshan, A. Thermal and catalytic degradation of Polystyrene with a Novel catalyst. Journal emerging Technologies. 5: 234-238. 2013. 